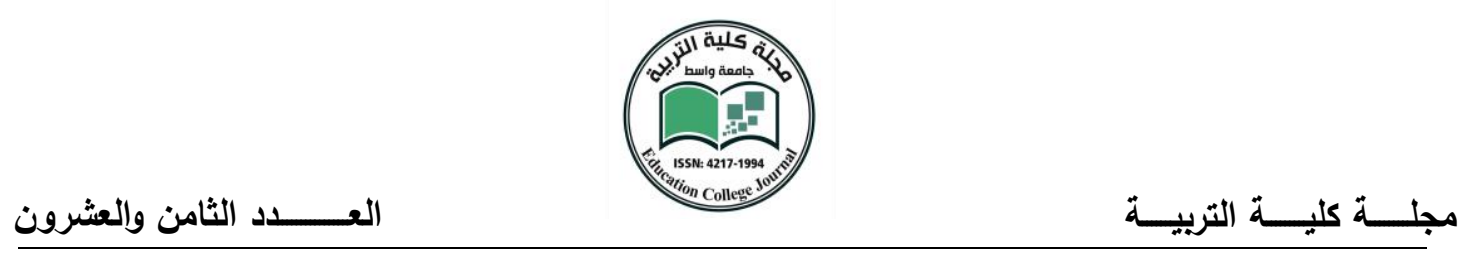

\title{
EVIDENTIALITY IN PUTIN'S POLITICAL SPEECHES ON TERRORISM
}

\author{
ASST. LEC. ALI HAIF ABBAS \\ UNIVERSITY OF WASIT \\ COLLEGE OF EDUCATION
}

\begin{abstract}
This research attempts to study evidentiality through analysing some selected quotations of Vladimir Putin's political speeches on terrorism. Violence crisis has been escalated since 2013 and till now in Iraq and Syria due to the emergence of different terrorist organisations. It is extremely important to know the reasons behind the growth and development of terrorism in recent years. If one takes the definitions which dealt with terrorism in the world, he/she can find that there is no fixed definition to terrorism. What is considered a terrorist in some countries is considered a fighter (mujahid) in others. Thus, killing thousands of Iraqis from the point of view of some states is resistance and Jihad, while these same actions are classified as "terrorist acts" when implemented in other countries. The financing of terrorist groups is behind the continuation of the terrorist-brutal operations on innocent civilians. The study aims at understanding the concept of evidentiality and its role in political discourse analysis. The study also aims to make everything clear to the public regarding the reasons which led to the emergence of terrorist organisations and the countries that support them based on the facts which Putin will present through his speeches. In order to achieve the aims, the study offers two hypotheses: Putin is certain from his information sources regarding the countries which finance the terrorists. Putin also uses different evidentials to reinforce the accuracy of his information. The study introduces the concept of evidentiality, its approaches, and significance in detail. In order to solve the problem of the study and achieve its aims, the researcher adopted two models: Chafe (1986) and Mushin (2001). Based on the analysis of data, the study explored that there are countries clearly support and finance terrorists, and Putin uses different evidential markers to reinforce the sources of his information. The study addresses these countries to stop financing terrorists
\end{abstract}


يحاول هذا البحث دراسة الدلائلة من خلال تحليل بعض المقطوعات المختارة من خطابات

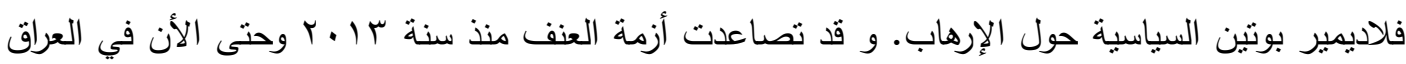

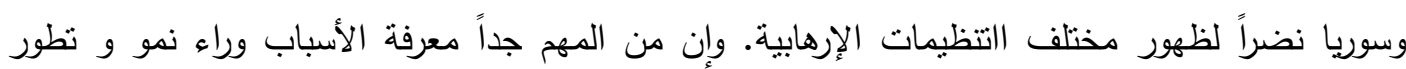
الإرهاب في السنوات الأخيرة.

إذا ما أخذنا التعاريف التي تتاولت الإرهاب في العالم، فيمكن ان نجد أنه لا يوجد تعريف محدد

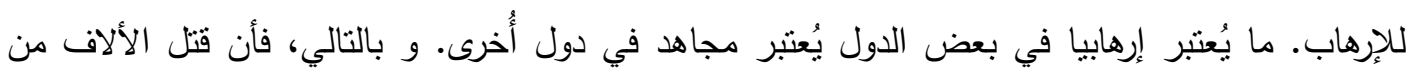

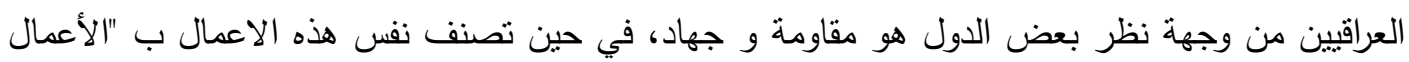
الإرهابية" عند تتفيذها في بلدان أخرى.

تهدف الدراسة الى فهم مفهوم الدلاثلية و دورها في تحليل الخطاب السياسي. وتهدف الدراسة ايضاً

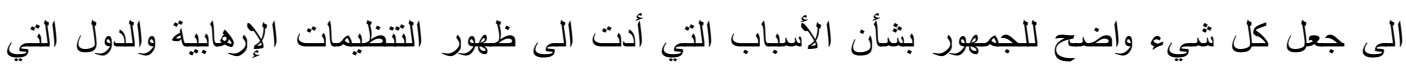
تدعمهم، مرتكزةً على الحقائق التي سيقدمها بوتين من خلال خطاباته.

من أجل الحصول على الأهداف، تعرض الدراسة فرظيتين: أن بوثين متأكد من مصادر معلوماته

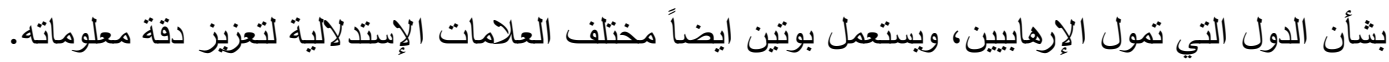
تقدم الدراسة مفهوم الدلائلية، ومناهجها، وأهميتهما بالتقصيل. ومن أجل حل المشكلة وتحقيق

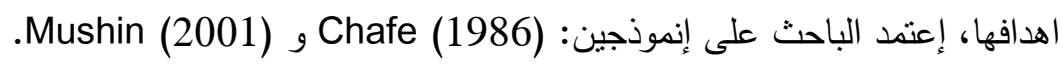

من خلا تحليل البيانات، كثفت الدراسة أن هناك دولاً تدعم وتمول الإرهابيين بشكل واضح، دئح

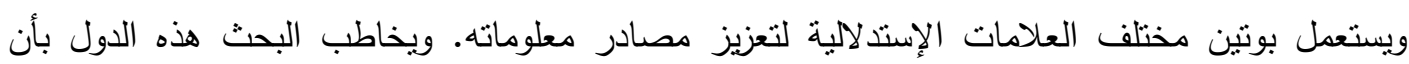
توقف تمويل الإرهابيين. 


\section{Review of Literature}

\subsection{Defining and Understanding Evidentiality}

Evidentiality has become a great topic in the field of linguistics recently. It focuses on the speaker's attitude towards the reliability of information and the source of information (Liu, 2016, p. 1).

According to Saeed (1997, p. 133), evidentiality is a term for the ways in which a speaker qualifies a statement by referring to the source of the information

Bybee (1985, p. 184) defines evidentiality as a marker that shows something about the source of the information in the situation in question.

Aikhenvald (2004, p. 1) illustrates that every statement should indicate the kind of source on which it is based. Sometimes, speakers hear it, see it, or deduce it from indirect evidence, or learn it from other people. This category which focuses on the information source is called "evidentiality".

These definitions of evidentiality are narrow, because they neglect the relationship between evidentiality and modality (Siau, 2013, p. 13).

Dendale and Tasmowski (2001, p. 343) illustrate that the evidential markers which mark the source of information also mark the speaker's attitude.

The relationship between evidentiality and modality comes from the fact that when one wants to present certain and reliable information, he/she should use direct evidence (sensory, visual), and if one wants to present less certain information, he/she should use indirect evidential categories (reported, hearsay) or inferred (obtained through reasoning). In this sense, evidentiality is commonly treated under the field of epistemic modality (Gonzalez et al, 2014, p. 2)

\subsection{History of Evidentiality}

According to Liu (2016, p. 2), the concept of evidentiality is first suggested by Boas (1911) in his research of 'American Indian Languages'. The word "evidentiality" was first used to express the source and certainty of information. 
Sapir (1921, p. 6-114) explains evidentiality in a long list of grammatical categories. These grammatical categories clarify and indicate the source of the speaker's information (whether it comes from actual experience, by hearsay, or by inference).

According to Bednarek (2006, p. 636), Jacobson $(1957,1971)$ also refers to the notion of 'evidentiality' as a provisional label for a verbal category that marks the source of the information on which a speaker's/writer's statement is based.

Concerns over evidentiality were developed when Chafe's (1986) and a set of papers under the title 'Evidentiality: the Linguistics Coding of Epistemology' were published. Journal of Pragmatics published seven selected papers on evidentiality and these papers were presented on the conference in 2001 in Reims. From that day on, evidentiality becomes an autonomous topic and draws the attention of so many linguists (Liu, 2016, p. 2).

\subsection{Approaches of Evidentiality}

This section sheds light on three main approaches of evidentiality. The approaches are: the typological approach, the pragmatic approach, and the cognitive approach. They are presented as follows:

\subsubsection{The Typological Approach}

Yang and Tian (2015, p. 400) demonstrate that Willett (1988) and Aikhenvald (2004) are the main scholars who made significant typological studies in evidentiality.

Liu (2016, p. 4) illustrates that Willett's (1988) typological studies in evidentiality consist of thirty-six natural languages and all these languages have typological features in common.

Aikhenvald (2004, p. 280) pays attention to the study of evidentiality as a grammatical category in its own right, and excludes it from other categories, especially, modality.

The typological studies in evidentiality give much emphasis to the grammatical categories of evidentiality in different languages, but not all languages 
have grammatical evidential categories and markers such as English and Russian. If one just pays attention to grammatical evidentiality, then it will be impossible to study evidentiality in English and many other languages which lack grammatical evidential markers. In this case, the typological approach to evidentiality is limited to the grammatical categories and markers in some languages, while both of lexical and grammatical markers of evidentiality should be considered (Yang and Tian, 2015, p. 400).

\subsubsection{The Pragmatic Approach}

The pragmatic approach indicates that the contextual factors are crucial in the study of evidentiality and should not be excluded. In most cases, speakers and writers choose some evidential markers that signal pragmatic implications. Such pragmatic implications downplay the speakers/writers direct involvement in the situation they present (Yang and Tian, 2015, p. 400).

Evidential markers have different meanings in context, and they provide readers and lay people facts about sensitive problems and issues which happen in everyday life. In this way, they attract researchers to explore all kinds of multidimensionality such as conventional implicature, conversational implicature, presupposition, illocutionary force, and accommodation (Davis et al, 2007, p. 73).

\subsubsection{The Cognitive Approach}

Evidentiality from a cognitive perspectives demonstrates that speakers/writers have the epistemological consideration of the information source and interaction setting before they choose their evidential markers (Yang and Tian, 2015, p. 400).

Chafe (1986, p. 261-272) distinguishes between the use of evidentiality in academic writings and conversations and finds out that there are differences between academic writing and conversational English due to the spontaneousness and interactiveness of speaking and the deliberateness and detachment of writing.

\section{4 Evidentiality in English and Russian}

Most of the studies in evidentiality found out that European Languages lack grammatical categories and markers (Siau, 2013, p. 18). 
According to Aikhenvald (2004, p. 209), every language has certain evidential markers and through these markers, one can know what other people talks and thinks about. Languages are different in what one must say, not in what one can say.

Evidentiality is expressed, in many languages, through grammatical markers such as affixes and particles, and these grammatical markers are not optional like English and other European Languages, but obligatory (Bednarek, 2006, p. 636).

The grammatical markers not only signal the information source but also they express pragmatic information and semantic properties such as inference. Such semantic properties vary in the degrees of certainty and reliability of the information source-as they are illustrated in the following examples in Makah and Quechua languages as follows (Speas, 2010, p. 1):

\section{Makah}

a. Wiki-caxa-w 'It's bad weather' (directly experienced).

b. Wiki-caxa-k-pid 'It looks like bad weather' (inference).

c. Wiki-caxa-k-it-wad 'I'm told it was bad weather'.

\section{Quechua}

a. Wanu-nqa-paq-mi 'It will die' (I assert).

b. Wanu-nqa-paq-shi 'It will die' (I was told).

c. Wanu-nqa-paq-chi 'It will die' (perhaps).

English and Russian languages do not have grammatical categories and markers to express evidentiality. Therefore, evidentiality in English and Russian is expressed through using functional system such as adjectives, adverbs, parentheticals, and indicative modality (Siau, 2013, p. 19; Paducheva, 2012, p. 34$35)$.

According to Barton (1993, p. 746), English does not have a well-defined grammatical system of evidential markers. In this case, a variety of optional-lexical means can function as evidentials. 
The modal verbs "may" and "must" are used as inferential evidential markers (Barrera and Toledo, 2013, p. 12).

Chafe (1986, p. 261) demonstrates that English has many evidential markers. Evidentiality in English can be expressed through modal auxiliaries, adverbs, and adjectives.

\subsection{Selection and Description of Data}

The data used in the analysis are made up of (13) selected quotations taken from Vladimir Putin's political speeches on terrorism. The researcher focuses on certain quotations which give emphasis on the development of terrorism as well as the financial and military supports that are given to many terrorist organisations.

Putin's political speeches on terrorism were chosen, because terrorism not only represents danger to the national security of Russian Federation but also it is very sensitive and dangerous to middle-eastern countries such as Syria and Iraq, which are suffering from terrorist violence and massacres every day.

The speeches are taken from the two Russian famous news channels, namely, the Presidential channel Kremlin, and RT in English. Putin's political speeches are taken from online sources, the main websites of the channels. The channels websites are: (en.kremlin.ru) and (www.rt.com).

\subsection{Chafe's Model of Evidentiality}

According to Bazerman and Prior (2004, p. 72), Chafe (1986) identifies three general categories of evidentials: first, degree of reliability evidentials evaluate the reliability of knowledge, with expressions such as probably, certainly, generally, and virtually. Second, evidentials specifying the mode of knowledge-belief, induction, deduction, sensory evidence, and hearsay-cover a range of expressions. Evidentials indicating knowledge based on belief, for instance include I think, I believe, and in my opinion. Evidentials indicating type of reasoning include seem (induction) and thus (deduction). Third, contrast evidentials mark contrast between knowledge and expectation, and include hedges and other contrastive expressions such as of course, in fact, but, however, nevertheless, and actually. 


\subsubsection{Degree of Reliability}

According to Chafe (1986, p. 264), one way in which any information can be qualified is through the use of expressions demonstrating the speaker's evaluation of its degree of reliability. English uses for this purpose adverbs, adjectives, and modals like obviously, clearly, probably, certain, likely, should, must, and will as in (1):

1. Certainly, several women loved him, and he was married twice (Swan, 2005, p. 157).

\subsubsection{Modes of Knowledge Evidentials}

\subsubsection{Belief}

The evidence in this mode of knowledge is downgraded. One believes things because he/she respects those who say these things or simply he/she wants to believe them. Sometimes, belief mode of knowledge is reinforced by other modes of knowledge such as degree of reliability and deduction to support evidence in which a believer may cite. Expressions marking this mode of knowledge are: I believe, I guess, I suppose as in (2):

2. I think it was Freddie Kruger (Biber et al, 1999, p. 362).

\subsubsection{Induction}

Induction or inference is the act or process of reaching a conclusion about something from known facts or evidence. The most common markers of this mode of knowledge are must, should, may, and might as in (3):

3. I wonder why Tom has not answered my letter - He might be ill (Thomson and Martinet, 1986, p. 148).

\subsubsection{Sensory Evidence}

In English, sensory markers such as see, hear, feel, taste, and smell indicate reliable knowledge as in (4), (5), and (6)-taken from (Chafe, 1986, p. 267): 
4. I see her coming down the hall.

5. I hear her taking a shower.

6. I feel something crawling up my leg.

Less degree of reliability knowledge is expressed through using less reliable sensory verbs such as looks like, sounds like, and feels like as in (7), (8), and (9):

7. She looks like she is a sleep.

8. He sounds like he is mad.

9. It feels like the door is open.

In contrast to the high degree of reliability shown in (4) and (6), (7) and (9) show a degree of doubt.

\subsubsection{Hearsay Evidence}

In everyday life, one can know many things because he/she has been told about them. Hearsay evidential markers such as say, tell, and hear can perform this function as in (10):

10. Lisa says she doesn't want to come (Biber et al, 1999, p. 375).

There are other less direct and doubtful hearsay markers such as it seems, supposed to, and apparently as in (11):

11. It seems that Bill and Alice have had a row (Swan, 2005, p. 508).

\subsubsection{Deductive}

Deductive mode of knowledge is concerned with predicting and reasoning. Deduction is a mode of using reason to form a conclusion or opinion about something. Such reason involves an intuitive leap to a hypothesis from which conclusions about evidence can be deduced. Markers that perform this function are should, would, can, could, and presumably as in (12):

12. Adults presumably are capable of purely logical thought (Chafe, 1986, p. 269). 


\subsubsection{Contrast Evidentials}

\subsubsection{Hedges}

Hedges are considered as expressions marking a proposition. Expressions such as sort of, kind of, about, and approximately can perform this function as in (13):

13. It is sort of/kind of raining (ibid).

\subsubsection{Expectations}

This evidential category is crucial in the study of evidentiality. It includes many evidential markers which indicate a belief that something will happen or is likely to happen. Large number of markers indicate expectations of some kind such as in fact, but, nevertheless, actually, of course, at least, oddly enough, however, and even as in (14):

14. I've got a new job. Actually, they have made me sales manager (Swan, 2005, p. 11).

\subsection{Mushin's Model of Evidentiality}

According to Mushin (2001, p. 1), evidentiality is a linguistic category through which the states of one's knowledge is expressed.

Yang (2012, p. 141) illustrates that Mushin's (2001) concentrates on the role of epistemological stance of the evidence in presenting information. The adoption of a certain epistemological stance in the representation of any information depends on the information source as well as the communicative goals.

Mushin (2001, p. 52-59) demonstrates that when speakers and writers present a piece of information, they take a stand on how they acquired the information and how they know it. This stand is their epistemological stance towards the information. There are five types of epistemological stance: personal, reportive, inferential, factual, and imaginative. They are presented as follows: 


\subsubsection{Personal Experience}

Adopting personal experience epistemological stance towards information depends on the speaker's direct and conscious perceptual experience. In many cases, the speaker is the only person who has access to the truth of the information. Expressions perform this type of epistemological stance are first person reference and the use of expressive language such as I go, I used to, I went, I have gone, etc.

15. I used to smoke cigarettes; now I smoke a pipe (Thomson and Martinet, 1986, p. 151).

\subsubsection{Inferential}

Inferential epistemological stance is expressed in the representation of information as inferred based on known facts or evidence. In this case, a conclusion is formed. Expressions that mark this type are: must, should, would as in (16):

16. Peter must be having a party on Saturday night (Mushin, 2001, p. 66).

\subsubsection{Reportive}

In this type, the information is acquired by virtue of what someone else has said. Verbs such as say, tell, and hear can perform this function as shown in (17):

17. John says that Peter is having a party on Saturday night (ibid, p. 69).

\subsubsection{Factual}

In this type of epistemological stance, there is no need to the evidential markers or source of information, because the information is assumed to be known by everybody as a general cultural knowledge, or the source of the information is unimportant to the validity of the information as in (18):

18. Two plus two equals four (ibid, p. 74). 


\subsubsection{Imaginative}

Imaginative epistemological stance represents information as embedded in some fictional story world. The imaginative epistemological stance represents certain information or event as more fictional or hypothetical as in (19):

19. It would be great if you came to Peter's party (ibid, p. 76).

\subsection{Data Analysis}

In this section, (13) quotations are chosen from Putin's speeches on terrorism, especially in Syria and Iraq. In order to have a successful evidentiality analysis, the following points need to be made:

1. Mushin's (2001) inferential, and reportive epistemological stances will be treated as Chafe's (1986) inductive (inference), and hearsay evidential categories respectively, because they have the same meaning, functions, and evidential markers.

2. Factual epistemological stance will be included in the field of high degree of reliability of the information source.

The selected quotations will be analysed in relation to the semantic and pragmatic aspects of evidentiality as follows:

\section{Quotation 1}

"Финансирование, как мы установили, идёт из 40 стран, причём в том числе из стран «двадцатки». Обсуждали эту тему. Я даже продемонстрировал нашим коллегам наши снимки из космоса и с самолётов, на которых ясно показано и видно, какие масштабы приобретает эта незаконная торговля нефтью и нефтепродуктами. Колонны автомашин-заправщиков растянуты на десятки километров, так что с высоты 4-5 тысяч метров они уходят за горизонт" (kremlin. 16 Nov, 2015).

Financing is coming from 40 countries, including G20 countries. I also showed our colleagues satellite images and aerial photographs that show very clearly the scale of this illegal trade in oil and petroleum products. You see columns of 
refueling vehicles stretching for dozens of kilometers in lines so long that from a height of 4000-5000 meters they vanish over the horizon

In this quotation, Putin uses personal experience stance in the phrase " $Я$ продемонстрировал" (I showed) which means 'to cause or allow something to be seen; to give information that proves something'. The evidential marker "ясно" (clearly) means 'in a way that is certain; without doubt'. Putin's use of the evidential marker "ясно" (clearly) illustrates that he is very sure from his information source. It indicates high degree of reliability of the information source. Through the use of "ясно", the listener should agree with the speaker (Vladimir Putin), because he is very sure from his information source regarding the countries which purchase the illegal oil and petroleum products from ISIS terrorists.

\section{Quotation 2}

"Мы же предложили сотрудничество на антиигиловском направлении. К сожалению, наши партнёры в Соединённых Штатах на первом этапе ответили отказом. Они просто в письменном виде направили ноту, и там написано: «Мы отклоняем ваше предложение». Но, действительно, жизнь развивается очень быстро и часто преподносит нам уроки. И мне кажется, что сейчас всё-таки осознание того, что эффективно бороться можно только вместе, приходит ко всем" (kremlin. 16 Nov, 2015).

We offered to cooperate \{with the US\} in anti-IS efforts. Unfortunately, our American partners refused. They just sent a written note and it says: 'we reject your offer'. But life is always evolving and at a very fast pace, often teaching us lessons. And I think that now the realization that an effective fight \{against terror\} can only be staged together is coming to everybody.

Putin's use of a factual epistemological stance in phrases such as "Мы же предложили" (we offered), "Они направили" (they sent), "Мы отклоняем" (we reject) implies that the information is known to the reader that Russia has offered to cooperate with the U.S. against ISIS and it is a fact. Putin's second statement (Они просто в письменном виде направили ноту, и там написано: «Мы отклоняем ваше предложение»-They just sent a written note and it says: 'we reject your offer') draws the attention to the way that knowledge of this information was acquired: the written note which says "Мы отклоняем ваше предложение"(we 
reject your offer) between single quotation represents the universally accepted information from a reportive epistemological stance. The evaluative adverb "сожалению" (unfortunately) not only indicates Putin's sadness but also gives the listener/reader clear information (evidence) that the Americans do not really want to cooperate with Russia against terrorism.

The word "Ho" (but) is a marker of evidentiality which signals expectations. It is used in three-part structure: first, there is discussion of facts that point in a certain direction. Second, it is agreed that a particular contradictory fact points the other way. Third, the speaker/writer dismisses this and returns to the other direction of the argument. The evidentiality marker "Ho" (but) gives three facts: first, the U.S. refused to cooperate with Russia against terrorism. Second, Russia wants to work together with the U.S. and the entire world against terrorism. Third, Putin disagrees with the U.S. regarding the idea of refusing the cooperation and insists that the only way to defeat terrorism is through working together. The speaker, Putin uses the "belief" expression "мне кажется" (I think). He, then, explicitly qualifies his commitment to the truth of his respective proposition. The belief expression expresses the deductive mode of reasoning by using "можно" (can). Such deductive reasoning involves 'intuitive' leaps to a hypothesis on the part of the speaker from which conclusion is deduced. Putin's "можно" indicates some degree of reliability in his mind which expresses the speaker's propositional attitude that there should be cooperation in order to achieve effective victory on ISIS.

\section{Quotation 3}

"Да и само «Исламское государство» возникло не на пустом месте: его также поначалу пестовали как орудие против неугодных светских режимов. Создав плацдарм в Сирии и Ираке, «Исламское государство» активно расширяет экспансию на другие регионы" (RT in English. 28 Sep, 2015).

In fact, the Islamic State itself did not come out of nowhere. It was initially developed as a weapon against undesirable secular regimes. Having established control over parts of Syria and Iraq, Islamic State now aggressively expands into other regions.

The evidential marker "Да и само" (in fact) is used to stress that a statement is known to have happened or to exist, especially the statement for which proof exists, or about which there is information. The word поначалу" (initially) means 
'at the beginning'. The word "неугодных"" (undesirable) means 'objectionable or challengeable'. Putin uses factual epistemological stance which indicates high degree of reliability of the information source regarding the purpose behind the emergence of ISIS: this quotation gives the reader a clear evidence that Putin is very sure that ISIS terrorist group is supported by powerful countries. They also give the reader evidence that ISIS has been planned for before.

\section{Quotation 4}

"MbI Считаем любые попытки заигрывать с террористами, а тем более вооружать их, не просто недальновидными, а пожароопасными. В результате глобальная террористическая угроза может критически возрасти, охватить новые регионы планеты" (RT in English. 28 Sep, 2015).

We consider that any attempts to flirt with terrorists, let alone arm them, are shortsighted and extremely dangerous. This may make the global terrorist threat much worse, spreading it to new regions around the globe.

In this quotation, Putin uses the word "Считаем" (consider). The word "Считаем" is similar to "think" and "believe" and it means 'to think that something may exist or may be true'. According to Putin's deductive reasoning, some countries are supporting and arming terrorists. The word"может" (тау) is used to talk about possibility: when one thinks that something is possible. The evidential marker "может" indicates that knowledge is acquired inferentially. Putin has deduced the fact that the idea of supporting terrorists and flirting with them is a wrong policy and extremely dangerous.

The supplement of Putin's speech after "может" (тау), "В результате глобальная террористическая угроза может критически возрасти, охватить новые регионы планеты"(make the global terrorist threat much worse, spreading it to new regions around the globe), further reinforces his inferential certainty that there was a global terrorist threat and now it may become much worse. It also shows his confidence in his deductive inferential information source.

\section{Quotation 5}

"Не нужно играть в слова, делить террористов на умеренных и неумеренных. Хотелось бы понять, в чём разница. Наверное, по мнению некоторых 
специалистов, в том, что умеренные бандиты, что называется, в умеренном количестве или нежным способом обезглавливают людей" (RT in English. 22 Oct, 2015).

We should not break down the terrorists into moderate and immoderate ones. It would be good to know the difference. Probably, in the opinion of certain experts, it is that the so-called moderate militants behead people in limited numbers or in some delicate fashion.

In this quotation, Putin uses a deductive mode of knowing. Deduction is concerned with predicting and reasoning. The word "нужно" (should) is used to indicate 'correctness' and is used to give a concluded fact based on the reasoning of the speaker. Such reasoning or inference involves an intuitive leap to a hypothesis from which conclusion about evidence is deduced.

Putin gives the reader/listener a deductive fact that terrorists should not be divided into moderate and immoderate ones and those who are fighting in Syria against the legal government are terrorists. Putin uses the word "бы" (would) to show his desire and provide responsibility for his evidence that there are no moderate terrorists. Putin's "бы" also indicates unreal, imaginative or hypothetical situation that the West till now does not want to know the fact that there are no moderate terrorists. The word "Наверное" (probably) is used to mean that something is very likely to happen. Then, Putin reinforces his evidence when he mentions the phrase "по мнению некоторых специалистов" (in the opinion of certain experts). According to Putin and the experts, it is the so-called moderate militants that beheaded and killed innocent people. The main fact Putin wants to say is that terrorists are terrorists and no one can change them into moderates.

\section{Quotation 6}

"Очему усилия, допустим, наших американских партнёров и их союзников по борьбе с «Исламским государством» не давали внятных результатов? Очевидно, что дело не в нехватке военного имущества или потенциала. Безусловно, Соединённые Штаты располагают огромным, самым большим в мире военным потенциалом, просто всегда трудно вести двойную игру. Объявлять о борьбе с террористами и одновременно пытаться использовать часть из них для того, чтобы расставлять фигуры на ближневосточной доске в 
своих интересах, как кажется, в своих интересах" (RT in English. 22 Oct, 2015).

Why is that the efforts of, say, our American partners and their allies in their struggle against the Islamic State has not produced ant tangible results? Obviously, this is not about any lack of military equipment or potential. Clearly, the United States has a huge potential, the biggest military potential in the world, only double crossing is never easy. You declare war on terrorists and simultaneously try to use some of them to arrange the figures on the Middle East board in your own interests, as you may think.

What is important in this quotation is Putin's use of high degree of reliability words: "Очевидно", (obviously), "Безусловно", (clearly), and "одновременно", (simultaneously) respectively. These adverbs illustrate that Putin is very sure from the information and that his information source contains high degree of reliability. The word "Очевидно" (obviously) means 'in a way that is easily to understand, perceive, or see'. It shows how information is gained. It gives an obvious fact and truth regarding the slow in the progress of the Americans and their allies struggle with ISIS terrorists. According to Putin, this slow progress is not due to lack of military capability in the U.S. Army. The word "Безусловно" (clearly) reinforces the idea of factuality concerning the proposition and it is more convincing. "Безусловно" (Clearly) means 'in a way that is easy to see, hear, read, or understand'. It is closer to "evidently". Through the use of "Безусловно", Putin is certain from his information source that the slow progress of the United States and its allies is not because of military potential because the United States has a huge potential. The word "одновременно" (simultaneously) means 'happening or being done at exactly the same time'. According to Putin, the United States does not have real intent to defeat terrorism, instead, it uses them as a bite to get rid of undesirable secular regimes and to serve its interests in the region.

\section{Quotation 7}

"Я уверен, что действия российских военных окажут необходимое воздействие на ситуацию в позитивном плане" (RT in English. 22 Oct, 2015).

I am sure that the Russian service members' actions will have the necessary positive effect on the situation. 
Putin, in this quotation, uses the word "уверен" (sure) in the sentence "Я уверен" (I am sure) and the word "окажут" (will) to express his confidence of the positive results of the Russian military operations against terrorism. The word "уверен" (sure) means 'impossible to doubt or dispute; certain that something is real, true, or correct'. Putin's use of "уверен" not only means that the Russian military operation succeeds in Syria but also convinces the public that it is serious and has positive effect on the situation. Then, Putin, uses the future marker "окажут" (will) with a denoting meaning. The word "окажут" is used to express certainty or confidence about present or future situation. It reinforces the idea of factuality concerning the proposition.

\section{Quotation 8}

"тем не менее всё-таки почти полтора года коалиция во главе с Соединёнными Штатами наносила там удары, свыше 11 стран приняли участие, свыше 500 ударов нанесено по разным целям, но результата-то нет, это же очевидный факт. Какой же там результат, если за это время террористы только усилили своё присутствие на территории Сирии и Ирака, закрепились на тех рубежах, где они были, и расширили ареал своего пребывания. Поэтому в этом смысле, конечно, пока нашим коллегам ничего сделать не удалось, на мой взгляд, эффективного" (kremlin. 22 Oct, 2015).

Over the nearly 18 months that a US-led coalition has been carried out airstrikes, with more than 11 countries taking part and more than $\mathbf{5 0 0}$ strikes against various targets, there is no results yet, and this is a clear fact. Of course, our colleagues have not achieved any effective results as yet.

Putin uses clear and direct evidence that represents information commonly known by himself and the speech community as general cultural knowledge and he gives many facts regarding the slow progress of the U.S. and its coalition forces with their struggles against ISIS terrorists such as the long period which is nearly to полтора года (18 months), 11стран (11 countries) taking part in the offensive, and 500 ударов (500 strikes) against various targets without any achievements. Putin also uses obvious evidence through the use of the phrase "очевидный факт" (clear fact). This phrase indicates high degree of reliability in the information source. The expectation marker "конечно" (of course) is used to show that what one is saying is obvious or already known. It signifies certainty: the clear fact of this quotation is 
that the negative results of the U.S. war against ISIS push Putin to conclude (through observation) that the U.S. does not have real intentions to eliminate the so-called ISIS in the region.

\section{Quotation 9}

"Американские военные уже передают комплексы борьбы с танками и бронемашинами, бронетехникой и обучают расчёты. Думаю, что это большая ошибка. Полагаю, что это оружие наверняка попадёт в руки террористических организаций" (RT in English. 22 Oct, 2015).

The American military are already providing anti-tank and anti-armour weapons systems and are training gunners. I think this is a major mistake. I believe that this weaponry will certainly fall into the hands of terrorist organisations.

The phrases "уже передают" (are already providing) and "обучают" (are training) contain high degree of reliability in the information source. The phrases are important in showing Putin's really intended message to the public. From a factual epistemic viewpoint such markers communicate 'certainty'. Putin knows very well and is very sure that the American military provides support and trains to what he calls "gunners". The use of the present progressive tense indicates that these supports are continuing. The word "yже" (already) is used for saying that a situation has started to exist and still continues. He wants to give the reader a clear fact that the U.S. military are providing and training "gunners". He, then, uses "belief" mode of knowing "Думаю" (I think). The "belief" mode of knowing refers to his state of mind in which trust or confidence is placed in the fact that supporting and training gunners are wrong. Putin also uses the "belief" mode of knowing "Полагаю" (I believe) regarding the U.S. support to gunners. He reinforces his evidence through using the word "наверняка" (certainly). The word "наверняка" is used to emphasise something and show that it is true and there is no doubt about it. He is definitely sure from his information source. The main fact that he (Putin) wants to say is that: the U.S. weaponry will inevitably fall into the hands of terrorist organisations.

\section{Quotation 10}

"Как вы знаете, наши американские коллеги просто перешли к практике сбрасывания с самолёта вооружения и боеприпасов в определённые районы. 
К кому попадёт это вооружение и боеприпасы, кто их будет использовать, против кого? Уверенности нет, просто 100 процентов это знаю, нет никакой уверенности ни у кого, в том числе и у тех, кто это делает. Даже если на первом этапе попадёт в нужные руки, завтра может оказаться и, скорее всего, окажется у ИГИЛ или у «Джабхата ан-Нусры» и других организаций и иже с ними. Считаю, что и это большая ошибка" (kremlin. 22 Oct, 2015).

Moreover, as you know, our American colleagues simply chose to airdrop weapons and ammunition in certain areas. Who will receive this weaponry? Who will use it? Against whom? There is no certainty; I simply know 100\% that nobody can be certain of this, including those who do it. Even if it initially makes it into the right hands, tomorrow, it might and very likely will end up in the hands of ISIS or Jabhat al-Nusra or other similar organisations. I feel this is a big mistake.

Putin's speech in the first lines of this quotation indicates that the idea of U.S. military support to certain gunners in certain areas becomes a fact and it is fully true. Putin knows $100 \%$ that nobody can guarantee that the weapons will fall into the right hands. The factual stance that is said by Putin regarding the U.S. military support to "gunners" represents information commonly known by the speech community via a range of public sources such as the media, U.S. media, officials, and famous politicians, and public announcement and it is a fact without any doubt. The expectation marker "Даже если на" (even if) is used in a supposition or hypothesis. It refers to an imaginary or unreal situation. It is used to introduce a hypothetical condition that is not yet true. Putin's use of "Даже если на" gives the reader a fact that the weapons are not even given to the right hands. Then, he reinforces his evidence through using the evidential markers "может" (might), "скореe всего" (likely), and "окажется" (will). The word "может" is used for saying that there is a possibility that something is true, or that something will happen, especially, when it is not very likely. This possibility is again reinforced through the use of "скореe всего". The word "скореe всего" is used to show that something probably happens or is expected. The word "окажется" (will) finally reinforces the factuality of Putin's statement regarding the wrong decision of arming gunners. The sensory evidential marker "Считаю" (feel) is used here by Putin to report an assessment of mental state of being (I feel this is a big mistake). It is used to report reactions and disagreement to some previous fact or suggestion. 


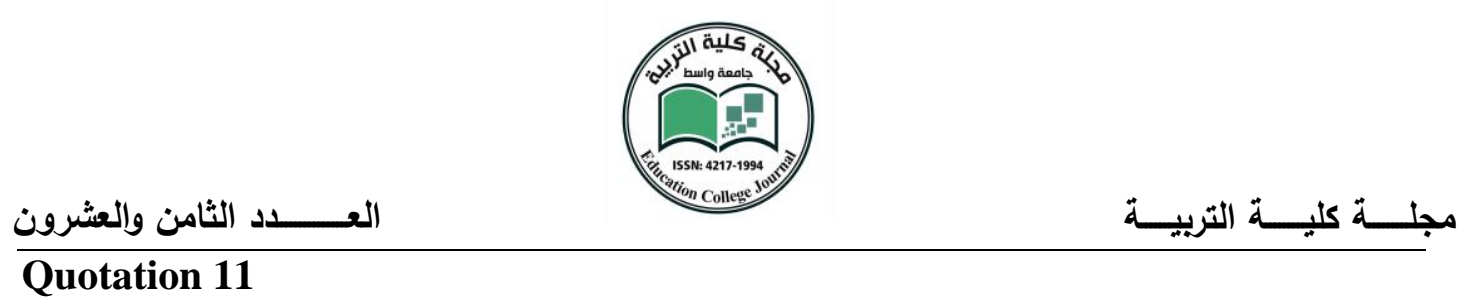

"Интервенции в Ираке и военное вмешательство в Ливии, привели к росту терроризма и экстремизма, это вообще абсолютно всем сегодня понятно, появлению таких зловещих феноменов, как так называемое Исламское государство - ДАИШ. Террористы не без успеха пытаются воспользоваться сломом государственных систем и результатами неуклюжих, прямо скажем, экспериментов по экспорту демократии в регион Ближнего Востока и Северной Африки. Сейчас только ленивый не говорит об этом. Было бы смешно, если бы не было так грустно, если бы не было столько трагедий" (kremlin. 30 Jun, 2016).

The military intervention in Iraq and Libya are the most vivid examples of this irresponsible and mistaken policy that has led to a rise in terrorism and extremism. It is clear to everyone today that this policy has contributed to the emergence of menacing organisations such as the Islamic State (DAISH). Terrorists have tried to turn to their advantage, and not without success, the breakdown in state systems and the results of, frankly speaking, clumsy experiments in exporting democracy to parts of the Middle East and North Africa. Every man and his dog talks about this now. It would be funny if it were not so sad, and if it were not the cause of so many tragedies.

In this quotation, Putin also uses factual epistemological stance regarding the reasons behind the emergence of terrorism: the military intervention in Iraq and Libya are behind the emergence of terrorism and extremism. Putin an indirect way refers to the NATO military intervention in Libya and the U.S. and its coalition forces military intervention in Iraq. He uses high degree of reliability evidential marker "понятно" (it's clear) to prove that he is sure from his information sources regarding the first reason behind the violence in Iraq and Libya. That is due to this wrong policy, DAISH and other terrorist organisations have emerged. He also uses the word "прямо скажем" (frankly) and it is used when giving an honest and direct opinion, often one that might upset someone. After "прямо скажем", Putin mentions the statement "экспериментов по экспорту демократии в регион Ближнего Востока и Северной Африки. Сейчас только ленивый не говорит об этом. Было бы смешно, если бы не было так грустно, если бы не было столько трагедий" (clumsy experiments in exporting democracy to parts of the Middle East and North Africa. It would be funny if it were not so sad, and if it were not the 
cause of so many tragedies). The statement gives the second reason that led to the emergence of many terrorist organisations which is the idea of exporting the fake democracy to these regions. Putin, then, uses the deductive mode of knowing "бы" (would) which involves an intuitive leap to a hypothesis from which conclusion is deduced. The evidential marker "бы" provides responsibility for evidence. He emphasises that these wrong policies are behind the cause of so "столько трагедий" (many tragedies).

\section{Quotation 12}

"Я не устаю удивляться тому, как наши партнёры раз за разом, как у нас в России говорят, наступают на одни и те же грабли, то есть совершают одни и те же ошибки. Своё время они спонсировали исламские экстремистские движения для борьбы с Советским Союзом, которые прошли закалку в Афганистане. Из них выросли и «Талибан», и «Аль-Каида" (kremlin. 24 Oct, 2014).

I never cease to be amazed by the way that our partners just keep stepping on the same rake, as we say here in Russia, that is to say, make the same mistake over and over. They have sponsored Islamic extremist movements to fight the Soviet Union. Those groups got their battle experience in Afghanistan and later gave birth to the Taliban and Al-Qaeda.

Putin uses another indirect way to refer to the wrong policies of the U.S. and the West and due to these wrong policies many terrorist organisations have emerged in the region. According to Putin's information source, Islamic extremists have been sponsored by the West and U.S. to destroy the Soviet Union in Afghanistan. Because of this, the Taliban and Al-Qaeda was created. Putin also uses factual epistemological stance which does not need high degree of reliability evidential markers and does not need reliable information sources because when a speaker uses factual epistemological stance, he/she is very certain from his information and he/she already mentions known facts in the public sphere.

\section{Quotation 13}

"Финансовая идёт от нефти, её добыча развёрнута на территориях, подконтрольных террористам. Они её продают по бросовым ценам, 
добывают, транспортируют. Ведь кто-то её покупает, эту нефть, перепродаёт, зарабатывает на этом, не задумываясь, что тем самым финансирует террористов, которые рано или поздно могут прийти и на их территорию, придут сеять смерть в их страны" (kremlin. 24 Oct, 2014).

The terrorists are getting money from selling oil too. Oil is produced in territory controlled by the terrorists, who sell it at dumping prices, produce it and transport $i t$. But someone buys this oil, resells it, and makes a profit from it, not thinking about the fact that they are thus financing terrorists who will come sooner or later to their own soil and sow destruction in their own countries.

In this quotation, Putin uses the phrases "Финансовая идёт от нефти"(financing is coming from oil), "террористам продают"(terrorists sell it), "Ведь кто-то её покупает, перепродаёт, финансирует террористов" (someone buys it, resells it, and finances terrorists). Adopting factual epistemological stance in the above quotation as it contains important information implies that Putin is very sure from his information sources, everyone knows this information as generally cultural knowledge, and no need to mention the information source because it is unimportant and everybody knows it. Putin's statement indicates that he knows very well that the terrorists are selling oil at low prices. He is very sure that this oil is purchased by countries and this fact allows readers to conclude that these countries which buy their oil, are also financing them. The evidential marker "придут" (will) is used to give certainty or confidence in future situation. According to Putin, the terrorists and after accomplishing certain goals and interests will return back to their masters and make heinous crimes. The following table presents the used evidential categories in the quotations quantitatively in terms of numbers and percentages as follows: 
العــــــد الثامن والعشرون

مجلــــة كليــــة التربيـــة

Table 3-1: Distribution of evidential categories, their numbers, and percentages in the analysed quotations.

\begin{tabular}{|c|c|c|}
\hline Evidential Categories & Numbers & Percentages \\
\hline Belief & $\varepsilon$ & $1 . \%$ \\
\hline Deduction & $\varepsilon$ & $1 . \%$ \\
\hline Expectation & $\varepsilon$ & $1 . \%$ \\
\hline Hearsay (Reportive) & 1 & $r \%$ \\
\hline High Degree of Reliability & $r$ & $0 \Sigma \%$ \\
\hline Imaginative & 1 & $r \%$ \\
\hline Induction (Inferential) & $r$ & $0 \%$ \\
\hline Personal Experience & 1 & $r \%$ \\
\hline Sensory & 1 & $r \%$ \\
\hline
\end{tabular}

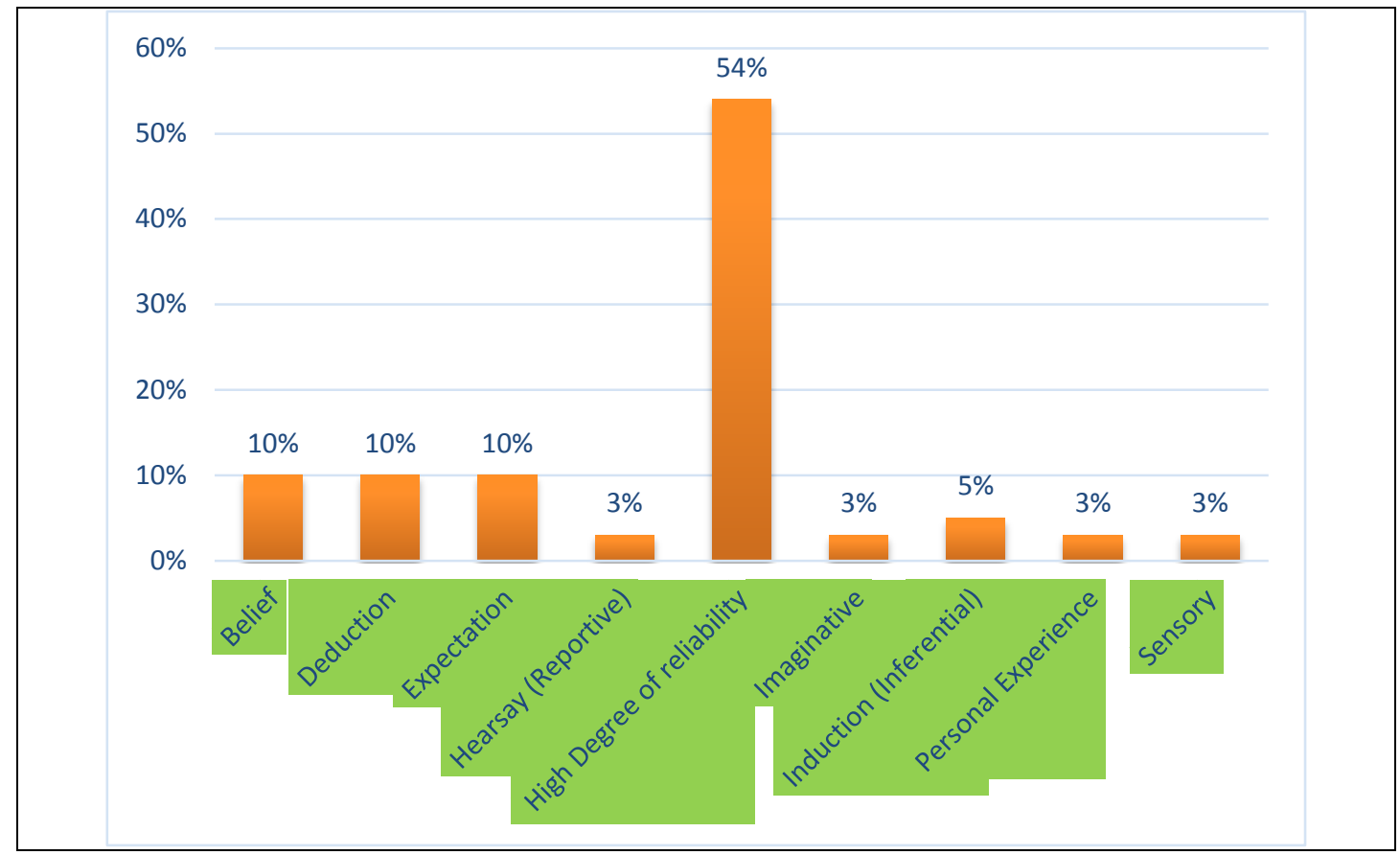

Figure 3.1: Percentages of the evidential categories used by Putin in the analysed quotations. 


\subsection{Results}

In most of the analysed quotations, Putin emphasises and concentrates more on supporting, financing, and growing of terrorism in recent years. The following results are extracted from the analysis:

1. In terms of supporting and financing terrorism, Putin is very clear and uses different evidential categories and markers in his information regarding the countries which finance terrorists. He uses high degree of reliability evidential markers, belief, and deductive modes of knowledge. He also reinforces his evidence through using factual epistemological stance. Although the names of these countries remain unknown, but it is true that there are countries that finance the terrorists in Iraq and Syria through purchasing their illegal oil.

2. In terms of military support, the United States and the West are supporting what Putin calls "gunners" fighting in Syria. Although Putin does not use the term "terrorists", but he is sure that this military support will not fall into the right hands, instead, it will fall into the terrorist hands. Putin also uses factual epistemological stances, high degree of reliability, belief, deductive, and inductive or inference modes of knowledge and he is very sure from his information sources regarding the U.S. support to "gunners".

3. In terms of growing of terrorism in recent years, Putin mentions a known fact that terrorism has grown rapidly in recent years. According to Putin's evidentiality markers, this rapid growth in terrorism is due to the use of terrorism by the West and the U.S. to achieve political goals and interests, military intervention in Iraq, Libya, and North Africa, exporting democracy, refusing to work together with Russia, and lacking the real intentions of fighting terrorism. Putin uses high degree of reliability evidential markers, belief, deductive, expectation modes of knowledge and factual epistemological stances to reinforce his evidence.

4. Based on Putin's modes of knowing, terrorists are immoderate. This is a fact and nobody can change them into moderates. The Russian military operation against terrorism in Syria is serious and factual and does not lack determination. Russia also does not fight terrorism to achieve political goals or interests. 


\subsection{Conclusions}

The term "evidentiality" literally educes the notion of evidence; the source from which a speaker comes to know something that he/she wants to express in language. Putin uses different categories and markers of evidentiality to reinforce his information sources regarding the reasons which led to the growth and emergence of many terrorist organisations as well as the political, financial, and military support of some countries to these terrorist organisations. Based on the results of data analysis, the following findings have been arisen as follows:

1. Putin uses different evidentials such as degree of reliability evidential markers, factual epistemological stances, inference, belief, and deduction to reinforce his evidence. This means that he is sure from his information. This verifies hypothesis (2) of the study.

2. Out of Putin's thirteen analysed quotations, eleven quotations are devoted to the growth, financial, and military support of some countries to terrorist organisations. According to Putin's information sources, it is because of these financial and military supports that these terrorist organisations have expanded into the world in general and Iraq and Syria in particular. This verifies hypothesis (1) of the study. 


\section{References}

Aikhenvald, A. (2004). Evidentiality. Oxford: Oxford University Press.

Barrera, O. I. and Toledo, Q. E. (2013). May and Must as Inferential Evidential Markers in a Corpus of English Scientific Texts. University of Las Palmas de Gran Canaria.

Barton, E. L. (1993). Evidentials, Argumentations, and Epistemological Stance. College English. 55: 745-769. Web. 23 Apr. 2017.

Bazerman, C. and Prior, P. (2004). What Writing Does and How It Does It: An Introduction to Analysing Texts and Textual Practices. Mahwaw: Earlbaum.

Bednarek, M. (2006). Epistemological Positioning and Evidentiality in English News Discourse: A Text-Driven Approach. Walter de Gruyter.

Biber, D., Johansson, S., Leech, G., Conrad, S. and Finegan, E. (1999). Longman Grammar of Spoken and Written English. Harlow: Pearson Education Limited.

Bybee, J. (1985). Morphology: A Study of the Relation between Meaning and Form. Amsterdam: John Benjamins.

Chafe, W. (1986). Evidentiality in English Conversation and Academic Writing. In W. Chafe and J. Nichols (eds.), Evidentiality: The Linguistic Coding of Epistemology. Norwood: Ablex Publishing.

Davis, C., Potts, C. and Speas, M. (2007). The Pragmatic Values of Evidential Sentences. In T. Friedman and M. Gibson (eds.). New York: Cornell University.

Dendale, P. and Tasmowski, L. (2001). An Introduction: Evidentiality and Related Nations. Journal of Pragmatics. 4.2: 339-348. Web. 1 May. 2017.

Gonzalez, M., Roseano, P., Borras, J. and Prieto, P. (2014). Epistemic and Evidential Marking in Discourse: Effects of Register and Debatability.

Lingua. 1-20. Web. 1 May. 2017.

Liu, Z. (2016). Evidentiality in Chinese. International Journal of Linguistics. 8.2:

1-11. Web. 3 May. 2017.

Mushin, I. (2001). Evidentiality and Epistemological Stance: Narrative Retelling.

Amsterdam: John Benjamins.

Paducheva, E. (2012). Evidentiality in Russian. Leiden.

Saeed, J. (1997). Semantics. Blackwell Publishers.

Swan, M. (2005). Practical English Usage. Oxford University Press.

Sapir, E. (1921). Language: An Introduction to the Study of Speech. New York: Harcourt, Brace and Company. 
Siau, A. (2013). A Corpus Based Analysis of Evidentiality in Popularised Scientific Discourse. Ghent University.

Speas, P. (2010). Evidentials as Generalized Functional Heads. University of Massachusetts.

Thomson, A. J., and Martinet, A. V. (1986). A Practical English Grammar. Oxford University Press.

Yang, L. (2012). A Comparative Study of Evidentiality in RAs in Applied Linguistics Written by NS and Chinese Writers. Shanxi University. . and Tian, Y. (2015). A Cross-Disciplinary Study of Evidentiality in Abstracts of English Research Articles. Shanxi University.

\section{PUTIN'S SPEECHES WEBSITES}

1. en.kremlin.ru/responses to journalists' questions following the G20 summit (16 Nov. 2105).

2. www.rt.com/70th session of the UN general assembly (28 Sep. 2015).

3. www.rt.com/meeting of the valdai international discussion club (22 Oct, 2015).

4. en.kremlin.ru/meeting of Russian Federation ambassadors and permanent envoys (30 Jun, 2016).

5. en.kremlin.ru/meeting of the valdai international discussion club (24 Oct, 2014). 